\title{
BUILDING COALITIONS: Working With Diverse Cultures
}

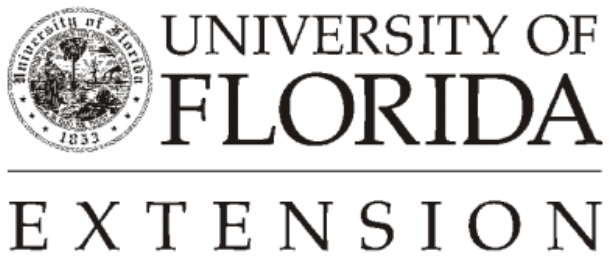

Institute of $\mathbf{F}_{\text {ood and }} \mathbf{A}_{\text {gricultural }} \mathbf{S}_{\text {ciences }}$ 


\section{Culturally Diverse Coalitions}

Brazzel defines diversity in terms of human differences that play an important role in the culture and operation of organizations. The culture of an organization includes the customs, assumptions, beliefs, values, rules, norms, practices, arts and skills that define and guide members by:

1. The reasons for existence of the organization.

2. How its "work" is to be done.

3. The rules for membership.

4. How to relate to others in the organization and to those outside.

Cox states that prejudices are negative personal attitudes toward members of a cultural group; discrimination is "observable adverse behavior" toward a group members.

Discrimination requires prejudice plus organizational or dominant-group power to lead to destructive denial of recognition, power and privilege.

The dimensions of diversity in organizations include:

- $\quad$ Age

- Educational background

- $\quad$ Ethnicity

- $\quad$ Family status

- Gender

- Income

- $\quad$ Military experience
- National, regional or other geographical areas of origin

- Ownership of property and assets

- $\quad$ Physical and mental ability

- Sexual orientation

- Social class

- $\quad$ Spiritual practice

- Work experience

These dimensions need to be considered when identifying, selecting, and recruiting prospective coalition members. A heterogenous group can work together effectively on mutual goals and objectives through consensus and cooperation. 
For an example: a neighborhood in a Midwestern city might contain several political subdivisions, a native American group, an African-American population, some small businesses, blue collar workers, a variety of religious groups and possibly some gang factions.

If a coalition is to be formed to obtain more housing, people from each or most of these groups must participate for the coalition to have power. If not participating, at least all cultural groups must be considered for their opinions or beliefs. A culturally-diverse coalition is composed of representatives of the cultures living in an area or community. It is also critical to consider varied opinions or beliefs within a certain culture. Two people do not have the same opinions because they are both native Americans or from an Appalachian culture.

\section{Definitions}

Culturally Diverse Pluralism--A culture that promotes mutual self respect, acceptance, teamwork and productivity among people who are diverse in age, gender, sexual orientation, ethnicity, race, class, religious beliefs, physical ability and other perceived differences.

Coalition--A unit composed of distinct elements of the population it serves.

Multicultural Organizations--Organizations that maintain a pluralistic culture promoting mutual respect, acceptance, teamwork and productivity among diverse people. It reflects the interests and contributions of members of diverse groups in mission, operations and product or service.

Diverse coalitions are well represented in multicultural organizations at all levels, in all functions and in all work groups. Members of diverse groups have power and influence in the organization. They are included as full and influential participants in all respects of the organization, especially where decisions are made and policies established. Discrimination is not tolerated within the organization and in its relationships with people, groups and organizations in its environment.

Discrimination-- The systematic, intended or unintended denial of recognition, power and privilege to certain people based on the groups to which they belong.

Cultural Bias--Cox includes discrimination and prejudice as apart of cultural bias. He states that prejudice is a "judgement made about others that reinforces a superiority/inferiority belief system."

Stereotype--A fixed and distorted generalization made about all members of a particular group. (Loden and Rosener) 


\section{Making the Most of Diversity}

Often, a culturally diverse youth/family coalition is viewed in the negative sense, rather than the positive. It is easy to identify the inherent obstacles and barriers associated with differences in religion, class, age, disability, veteran status, sexual orientation, region of origination, educational level or even paid employees versus volunteer staff.

The first phase of making the most of diversity is to make a concerted effort to become aware of what dimensions of cultural diversity exist within an organization. Acknowledging there are differences between individuals and groups of people is an important initial phase.

When conflicts, ill feelings, or stressful situations arise due to the sub-cultures involved, it is because of "differences." The second phase of making the most of diversity is for people to talk about their cultural differences. Two things must be remembered concerning cultural diversity:

- $\quad$ People should remember it is difficult to address cultural differences without resorting to stereotypes. In the purest form, there is no such thing as a stereotype. No person is exactly like another person and no individual is a clone of another member of a group.

- As diversity in an organization grows, so does the complexity of communication and the necessity to expend greater effort developing improved communication skills.

Awareness and discussion can bring about a clearer picture of cultural diversity. Appreciation and understanding of cultural diversity means not just tolerating differences among individuals or groups, but supporting and nurturing them. A variety of ideas, talents, skills, and knowledge is a desirable attribute to any youth or family coalition.

Providing a supporting and nurturing environment enhances other goals of the coalition by exposing group members to new issues, ideas, information and cultures. Diversity creates opportunities for character development by teaching tolerance and respect for people and by encouraging concern for equity. A culturally-diverse coalition that values and nurtures people from all backgrounds is worthy of active participation. Such an organization will flourish and perpetuate.

Making the most of diversity in a youth or family coalition requires the commitment of all involved. Changing prevailing attitudes and assumptions is not easy. Often the only hope is to change behaviors rather than deep-seated attitudes. Members of a diverse coalition must be committed to what they are doing and address issues related to cultural difference.

There may be resistance to disturbing the status quo, but it is no excuse for avoiding change.

Attention to cultural diversity may be the necessary catalyst for making things happen. Coalitions of youth or family agencies that strive to address specific community needs and issues have no chance of 
success, or even continued existence, unless they mirror, understand and make the most of their community's cultural diversity.

\section{Enhancing the Dynamics}

According to the traditional melting pot theory, immigrants settled in America would shed the ways of the old countries and blend happily into one people. At least two essential fallacies are inherent in the melting pot theory. The first is that non-white Americans can ( or should) become like white Americans. The second is that non-white people do not have cultural significance in the New World. Both ideas have met with controversy and rejection.

Since the 1960s, the idea of a single monoculture has begun to deteriorate. It has given way to a more pluralistic society that continues to evolve through cultural integration and influence. These changes are commonly evident in fashion, dietary habits, entertainment, music, literature and sports.

Within the framework of a youth and family coalition, diversity empowers its members to capitalize on unique skills and areas of expertise. Careful attention must be given to mutual understanding and appreciation of individual differences. Strengthening the sense of positive cultural identity is an important aspect of establishing a viable coalition.

Individuals may consciously or subconsciously interject ethnic values, attitudes or behaviors into the dynamics of the larger group.

Factors that impact the extent to which diverse cultures interact with existing cultures are:

- The reason for immigration; what was sought and what was left behind.

- The place of residence; an ethnic or nonethnic neighborhood.

- The socioeconomic status; education and upward mobility.

- The political and religious ties to the ethnic group.

- The spoken languages.

- The extent of family intermarriage with or connection to other groups.

- $\quad$ The individual's attitude toward the ethnic group and its values.

The concern with diversity and related programming by Extension and other organizations is a result of changes in the workplace and general population. Brazzel cites that aspects of diversity are being incorporated into vision and mission statements of both for-profit and not-for-profit organizations. To 
ignore its impact on profits and other bottom line measures affects performance. Organizations as well as individuals are exploring the impact of this diversity.

The result is a growing recognition that multiple perspectives can benefit an organization's approach to opportunities and problem-solving. Loden and Rosener say this approach assumes "we will be more successful as individuals, work teams, organizations and a society if we acknowledge, respect and work with... dimensions of difference."

So, the case for building a culturally diverse or multicultural coalition is without question. The drastic change in the status quo of the U.S. population, labor force, race and ethnicity, and citizen status demands adaptation.

All families in this country have experienced the stresses of immigration and migration. While ethnic heritage may have become dimmed or forgotten, it continues to influence outlook and interaction with others. Under the pressure of accommodating new situations, many groups have been forced to abandon much of their ethnic inheritance.

To understand ethnic identities, it is important to realize the impact immigration has on families over succeeding generations. Second generations are more likely to reject the "ethnic" values of their parents and to strive to become "Americanized." Third or fourth generations frequently reclaim aspects of their heritage that were sacrificed by previous generations as they sought to assimilate.

As the United States experiences the growing pains of becoming a citizenry of descendants of early forbears, the challenges are apparent. Preserving our roots need not prohibit the effectiveness of diverse individuals or groups working together.

\section{Managing Cultural Diversity}

1. Recruitment-- Try to include people or organizations within the youth or family coalition that are representative of the community.

2. Diversity Training--Become aware of the cultural diversity of the coalition. Try to understand all its dimensions and seek the commitment of those involved to nurture cultural diversity. Address the myths, stereotypes and cultural differences that interfere with the full contribution of members.

3. Communications Within Coalitions--Remove the major barriers that interfere with people from diverse cultures working together. The best method to do this is through understanding and practicing better communication: 
- Learn to listen. Listen for what is really being said, not what you want to hear.

- Invite others to be a part of the discussion.

- $\quad$ Learn to communicate clearly and fairly.

- $\quad$ Do not misjudge people because of accent or grammar.

- $\quad$ Test for understanding. Ask questions to be certain you are clear on what is being said.

- $\quad$ Adapt your communication style to fit the situation. The telephone causes problems in understanding between cultures. Be explicit. Individuals from different cultures may react differently. Know with whom you are communicating.

- $\quad$ Use language that fosters trust and -alliance. Don't come on like "'gangbusters." Each person wants to succeed in this venture. Be calm and positive.

- When conflicts arise, the problem may result from style rather than content--strive for understanding. Review, revise, and revisit your main objective to be certain the content is clear. How you say something may be more important than what you say.

4. Different, But the Same--Men and women white and non-whites, volunteers and paid staff, middle-class and working class people are different, but much less different than they are the same. An appreciation and acceptance of both commonalities and differences are essential to effective working relationships.

5. Maintain the Commitment--Your coalition will become more connected with the community that it serves if it states publicly that having a diverse work force is a top priority. Continue to revisit the various components that address the awareness, understanding communication and nurturing of a culturally-diverse organization.

6. Provide Strong Leadership--Loden and Rosener believe the following leadership behaviors foster coalitions of diversity:

- $\quad$ Articulate pluralistic vision and values for the organization; show ways in which they are an integral part of the organization's mission and vision.

- Encourage and support discussion among people throughout the organization about the meaning of diversity and pluralism; show how to implement programs that can accomplish these goals. 
- Demonstrate ethical commitment to fairness and to the elimination of discrimination in all its forms inside the coalition and in the coalition's relationships to other people, groups and organizations.

- Understand the dimensions of diversity, use inclusive and valuing language, quote diverse sources, readily adapt to differences in communication styles of diverse people, display respect for human differences and be aware of and comfortable about dealing with diverse issues.

- Value ongoing personal learning and change, solicit views and opinions of diverse people, invite feedback about personal behavior and blindspots and be open to belief modifications and actions based on feedback.

- Mentor and empower diverse individuals and encourage others to do so as well. (Loden and Rosener)

\section{Value Diversity}

The Key to Success. Diverse coalitions will be more successful because of support from the community they represent. Goals must be established to encourage diversity in membership. Without diverse coalitions there is animosity produced within neighborhoods and communities regarding "us versus them."

Within a culturally diverse group new ideas are produced, communications are improved and bridges are built to the people needing services.

There are numerous benefits when coalitions value diversity:

- Culturally diverse coalitions could be viewed as legitimate advocates for the greater community by political, business and industry "power brokers." Jackson, Holvino and Cox state:

"Multicultural organizations...human differences are valued and seen as a competitive advantage for the organization."

- Coalition membership recognizes that no one set of cultural values is inherently better than another.

- $\quad$ People are not required (expressed or implied) to relinquish their cultural heritage as a condition of coalition membership.

- $\quad$ Appropriate communication and working relationships among coalition members of different cultures require mutual respect and some understanding of one another's culture. 
- Coalition members should have the opportunity to hear directly from others regarding one another's culture and values; by doing so members will tend to be more respectful of them, especially if the exchange takes place among personal acquaintances.

- Opportunities for personal acquaintance and communication over time will usually increase trust among the coalition membership.

- Careful facilitation and sensitivity must occur when coalition members of different cultures are brought together. This ensures cross-cultural understanding, coalition productivity and effectiveness.

- $\quad$ Cross-cultural learning among coalition members will involve making mistakes and learning from them. Avoiding or being reluctant to initiate or participate in a culturally diverse coalition due to fear of mistakes, competition or conflict must be overcome.

- Gaining personal and cultural respect for coalition members from different cultures will contribute to more frequent and effective working relationships among those who have mutual interests.

\section{Developing a Coalition Which Values Diversity}

Look intensively at the community (or communities) being served by the coalition. Look at the makeup of various groups or agencies currently projected to be represented in the coalition. Do they match?

Coalition membership needs to reflect specific cultures represented in the community. If cultures are "lumped" together, true diversity will not be achieved. For example, to say a coalition needs an Oriental representative does not take into account the numerous Eastern cultures such as Japanese, Chinese, Vietnamese and others. The other critical concern should be the amount of "Americanization" which influences communities. First generation Vietnamese will normally have stronger cultural ties than a fifth generation Chinese population.

Be certain the coalition is not only composed of agencies saying they represent various cultures. Individuals who are representative of diverse cultures must be a part of any successful coalition. Coalitions serving diverse cultures must be representative of these cultures.

\section{Summary}

Coalitions which are culturally diverse and serve diverse populations must:

- Be representative of their target community.

- Communicate clearly. 
- $\quad$ Emphasize the advantages of their cultural diversity.

- $\quad$ Encourage the positive outcome of interacting with these cultures.

In building coalitions, it is important that neither prejudice or discrimination be tolerated, with consequences outlined in the constitution and bylaws or operational agreement. Self-awareness and sensitivity training should be a prerequisite for coalition membership as well as initial and subsequent orientation and training.

Coalition leaders should help members understand cultural diversity, realize such diversity can strengthen the coalition and acquaint them with specific roles they can play in developing a diverse group. 


\section{References}

Brazzel, Michael. "Building a Culture of Diversity in the Cooperative Extension System: A Paper to Foster Dialogue and Discussion About Pluralism in Extension." ECOP and ES-USDS National Diversity Strategic Planning Conference, Denver, Colorado, September 1991.

Cox, Taylor, Jr. "The Multicultural Organization." Academy of Management Executive 5, No. 2 (1991 ): 34-47.

Cross, Elsie V. "Issues of Diversity." In Sunrise Seminars, edited by Dorothy Vails-Weber and Joseph Potts. NTL Institute, Vol. 2(1985): 15-19.

Jackson, Bailey W. and Evangelina Holvino. "Working With Multicultural Organizations: Matching Theory and Practice. " Conference Proceedings, Organization Development Network, 1986.

Jackson, Bailey W. Keynote Speech for Youth 2000 Conference, as reported in New Hampshire COSA Newsletter (November-December 1990).

Lauffer, Armond. "Rubbing Shoulders and Rubbing Wounds--Gender, Class, Culture and Identity in the Workplace." Careers, Colleagues, and Conflicts. Sage Publications, 1985.

Lee, L. "The Opening of the American Mind." Comell University, Forum (Winter, 1991): 2-5.

Loden, Marilyn and Judy B. Rosener. Workforce America: Managing Diversity as a Vital Resource, Homewood, Illinois: Business One Irwin, 1991.

McGoldrick, M. "Normal Families: An Ethnic Perceptive," In Normal Family Processes, edited by F. Walsh. New York: The Guilford Press, 1982.

Nestor, Loretta Gutierrez. "Managing Cultural Diversity in Volunteer Organizations." Voluntary Action Leadership (Winter, 1991).

Valuing Diversity - A Strategic Plan for Cultural Diversity in the North Dakota State University (NDSU) Extension Service. 5th Draft, August 30, 1991.

Valuing Diversity - Part III: Communicating Across Cultures. Copeland Griggs Productions, San Francisco, California. 


\section{Authors}

Bill Smith, Associate Professor, District Specialist, 4-H, Ohio Cooperative Extension Service, The Ohio State University.

Ann W. Miller, Assistant Professor, District Specialist, Home Economics, Ohio cooperative Extension Service, The Ohio State University.

Thomas Archer, Ph.D., Associate Professor, County Agent, 4-H, Ohio Cooperative Extension Service, The Ohio State University.

Carla E. Hague, Assistant Professor, County Agent, 4-H, Ohio Coperative Extension Service, The Ohio State University.

\section{(C)The Ohio State University}

DKHS Ohio Cooperative Extension Senvice

This series on Coalition Building was developed by The Ohio Center For Action on Coalition Development for Family and High Risk Youth, Richard Clark, Ph.D., Director. It has been adapted for County Extension Faculty in Florida to facilitate work with local and regional organizations and groups such as non-profits, cooperatives, county extension associations, and others that might benefit from a plan for working together to achieve support for mutual goals.

This document is FY508, Part 16 of the 16 part series adapted for use in Florida by Elizabeth B. Bolton, Professor, Community Development and Lisa Guion, Assistant Professor, Program Planning and Evaluation; Department of Family, Youth and Community Sciences, Florida Cooperative Extension Service, Institute of Food and Agricultural Sciences, University of Florida, Gainesville, 32611-0310.

Reprinted with permission March, 1997. Revised April, 2002.

The Institute of Food and Agricultural Sciences is an equal opportunity/affirmative action employer authorized to provide research, educational information and other services only to individuals and institutions that function without regard to race, color, sex, age, handicap, or national origin. For information on obtaining other extension publications, contact your county Cooperative Extension Service office.

Florida Cooperative Extension Service/Institute of Food and Agricultural Sciences/University of Florida/Christine Taylor Waddill, Dean 